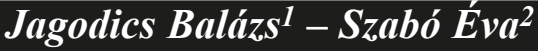

1 PTE-BTK Pszichológiai Doktori Iskola, Szociálpszichológia Doktori Program

2 SZTE-BTK Pszichológiai Intézet, Szociál- és Fejlődéspszichológiai Tanszék

\section{Egyetemi hallgatók normáinak összefüggése a motivációval és az észlelt oktatói kiégéssel}

Az egyetemi képzések sikerességének növelése olyan célkitüzés, amely mind a hallgatók, mind pedig az oktatási intézmények érdekét szolgálja. Magyarországon a felsốoktatási képzésekben nagyon magas, 30\% feletti lemorzsolódási arányt állapitanak meg a felmérések (Lukács és Sebö, 2015; Varga, 2010). Számos kutatás keresett választ arra a kérdésre, hogy milyen tényezók vezetnek a tanulmányok idó elótti abbahagyásához (Pusztai és mtsai, 2019; Richardson és mtsai, 2012; Szöllösi, 2019). Ezek egy része a pszichológiai tényezók, azokon belül is a motiváció szerepét hangsúlyozza (Czakó és mtsai, 2019; Pusztai és mtsai, 2019). A motiváció egyrészt egyéni jellemzó, amely fakadhat érdeklódésból vagy egyéb extrinzik célokból, másrészt viszont erôteljesen befolyásolhatják társas hatások is. Habár ezeket az összefüggéseket már korábban is vizsgálták, kutatásunk célja az volt, hogy a hallgatók motivációját és sikerességét egy kevésbé alkalmazott nézópontból, az észlelt csoportnormák szempontjából vizsgáljuk meg. Egyrészt választ keresünk arra a kérdésre, hogy milyen vélt és valós normák jelennek meg az egyetemi hallgatók. csoportjaiban, és ezek milyen kapcsolatban vannak a diákok célorientációs jellemzóivel, tanulási motivációjával. Másrészt megvizsgáljuk, hogy milyen hatással van a diákok motivációjára az, hogy hogyan észlelik tanáraik lelkesedését, illetve kiégettségét.

\section{A társas normák szerepe}

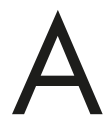
csoportok életében és működésében meghatározó szerepe van a közösen elfogadott vagy elfogadottnak vélt szabályoknak, vagyis a normáknak (Feldman, 1984). A közösségek tagjai motiváltak arra, hogy a közösség számára fontos értékeknek megfelelő, helyesnek tartott viselkedéseket kövessék. Ez a motiváció a kapcsolódás és a valahová tartozás szükségletéből fakad (Deci és Ryan, 1985; Fiske, 2004). A szociálpszichológiai fókuszú kutatások számos esetben rámutattak arra, hogy a csoporthoz tartozás iránti motiváció jelentős hatást gyakorolhat az emberek viselkedésére. Klasszikus vizsgálatok, például az Asch-féle (1956) vonalbecslési kísérlet mutatott rá a konformitás jelenségére, ami a viselkedés csoportnormához történő igazítására szolgál 
bizonyítékként. Későbbi kutatások szerint ezt nem csak a többség, hanem a csoporton belüli kisebbség konzisztens és magabiztos fellépése is kiválthatja (Moscovici és mtsai, 1969; Moscovici, 1977). A csoportok normáinak feltárása során Cialdini (1990) háromféle normát különített el. Az első a viselkedések gyakoriságán alapuló leíró norma, amely arra utal, hogy a csoporttagok mindennapos megnyilvánulásaira mi jellemző. A leíró normák akár külső megfigyelö által is észlelhetők, mert a tagok viselkedéséböl következtetni lehet a csoportot jellemző normákra. A második normatípus az elöíró vagy elrendelö norma, amely azt mondja meg, hogy egy adott viselkedésről mit gondolnak a csoport tagjai: az elfogadott és jutalmazott, vagy inkább elutasított a csoportban. A harmadik típusú normát a személyek egyedi meggyőződései adják, ezt nevezi személyes normának. A háromféle norma lehet egymással egybehangzó, kongruens, de az is elöfordul, hogy ezek nem teljesen egy irányba mutatnak, sőt ellent is mondhatnak egymásnak. Ilyen esetben fordulhat elö, hogy a konformitás akár olyan viselkedés kapcsán is létrejöhet, amivel a személy egyáltalán nem ért egyet, mégis követi a társakat az elutasítás elkerülése érdekében. Ennek a jelenségnek a hátterében a normák téves észlelése áll, amelyet a többszörös tudatlanság fogalma ír le (Bjerring és mtsai, 2014; Katz és mtsai, 1931; O’Gorman, 1986). Habár a kifejezés magyarul és eredeti angol formájában (pluralistic ignorance) is a tudás hiányára utal, valójában a csoporttagok véleményéről alkotott téves elképzeléseket jelenti, tehát inkább a tudás pontatlanságáról van szó, mint információhiányról (O’Gorman, 1986). Mivel azonban a hazai szakirodalomban is a többszörös tudatlanság kifejezés terjedt el (Smith és mtsai, 2016), a továbbiakban mi is ezt használjuk. A többszörös tudatlanság jelensége akkor fordul elö, amikor egy bizonyos viselkedéssel kapcsolatban a csoporttagok személyes attitüdje és a csoportnak tulajdonított attitüd között különbség keletkezik. Azaz személy szerint sokan nem kedvelnek egy adott viselkedést, de közben úgy vélik, hogy a többség ezt a viselkedést elfogadja vagy kedveli. Vagy éppen fordítva, személyesen mindenki elfogadja, de úgy hiszik, hogy a többség biztosan nem tartja követendőnek vagy helyesnek. Ezért a többszörös tudatlanság következtében elöfordulhat, hogy a csoporttagok viselkedését olyan normák irányítják, amelyek valójában nem is léteznek, csupán az észlelési
Klasszikus vizsgálatok, például az Asch-féle (1956) vonalbecslési kisérlet mutatott rá a konformitás jelenségére, ami a viselkedés csoportnormához történó igazitására szolgál bizonyitékként. Késóbbi kutatások szerint ezt nem csak a többség,

hanem a csoporton belüli kisebbség konzisztens és magabiztos fellépése is kiválthatja (Moscovici és mtsai, 1969; Moscovici, 1977). A csoportok normáinak feltárása során Cialdini (1990) háromféle normát különitett el. Az elsố a viselkedések gyakoriságán alapuló leiró norma, amely arra utal, hogy a csoporttagok mindennapos megnyilvánulásaira mi jellemzó. A leíró normák akár külsố megfigyeló által is észlelhetók, mert a tagok viselkedéséból következtetni lehet a csoportot jellemzó normákra. A második normatípus az elôiró vagy elrendeló norma, amely azt mondja meg, hogy egy adott viselkedésról mit gondolnak a csoport tagjai: az elfogadott és jutalmazott, vagy inkább elutasított a csoportban. 
torzításoknak köszönhetően tünnek valósnak. Ilyen torzítást eredményezhet, ha a negatív viselkedésekkel szemben tapasztalt passzivitást egyetértésként értelmezik a csoporttagok, nem pedig a felelősség megoszlásából következő egyéni reakcióként. A többszörös tudatlanság megjelenését számos kontextusban igazolták kutatások: megfigyelhető például egyetemisták között, akik hajlamosak túlbecsülni, hogy társaik mennyire nyitottak az alkoholfogyasztásra (Prentice és Miller, 1996; Schroeder és Prentice, 1998) vagy arra, hogy alkalmi romantikus kapcsolatokat alakítsanak ki (Lambert és mtsai, 2003). Továbbá az emberek hajlamosak túlbecsülni, hogy más csoportok tagjai mennyire távolságtartóak velük szemben (Shelton és Richeson, 2005), vagy hogy az emberek milyen mértékben támogatják a klímaváltozás problémáját kezelő kezdeményezéseket (Geiger és Swim, 2016). De a többszörös tudatlanság megjelenik a szervezetpszichológiában (Halbesleben és mtsai, 2007) és az üzleti etika területén (Halbesleben és mtsai, 2005) online térben is, a közösségi-média felhasználóinak körében (Hegyi és Jagodics, megjelenés alatt).

Középiskolások körében korábbi kutatások rámutattak arra, hogy az iskolai szabályokkal kapcsolatos pozitív, illetve a rendbontásra utaló negatív viselkedések esetében jellemző tendencia szerint jelenik meg a többszörös tudatlanság. A tapasztalatok szerint a pozitív viselkedések esetében saját véleményükhöz képest alul-, negatív magatartásformáknál pedig túlbecsülik a diákok az osztálytársaik elfogadó attitüdjét (Gajdics és mtsai, 2020; Jagodics és Szabó, 2019; Szabó és Labancz, 2015). Ez a különbség megjelenik az iskolai zaklatás esetében is, mert a diákok hajlamosak túlbecsülni azt, hogy társaik milyen mértékben támogatják az agressziót (Kóródi és mtsai, 2020). Tekintettel arra, hogy a többszörös tudatlanságot iskolai kontextusban vizsgáló kutatások a középiskolásokra koncentráltak, nem ismert, hogy az egyetemi hallgatók esetében megjelennek-e hasonló eltérések, így kutatásunk egyik fő célkitüzése ennek feltárása lesz. Feltételezzük, hogy a tévesen észlelt normák hatást gyakorolhatnak a tanulási motivációra is.

\section{Az észlelt tanári kiégés}

A pedagógusokat érintő kutatások gyakran számolnak be arról, hogy a tanárok és oktatók között magas a leterheltség és stressz hosszú távú következményeként kialakuló kiégés aránya (Bottiani és mtsai, 2019; Hakanen és mtsai, 2006; Lackritz, 2004). Ugyanakkor a kutatásoknak csak egy szúkebb része foglalkozik azzal, hogy a burnout-szindróma tüneteinek megjelenése a tanároknál milyen kapcsolatban van a diákok tanuláshoz való hozzáállásával, motivációjával. Egyes kutatások rámutatnak arra, hogy a tanulók észlelik, ha a tanáraik megváltoznak a kiégés megjelenésekor (Tatar és Yahav, 1999). Minél inkább fásultnak, kedvetlennek és motiválatlannak észlelik a pedagógusokat a diákok, annál kisebb észlelt támogatásról számolnak be (Shen és mtsai, 2015), és csökken a tanulás iránti motivációjuk is (Maslach és Leiter, 1999). Ugyanakkor a lelkes, tantárgyuk iránt érdeklődő pedagógusok diákjainál magasabb érdeklődés és pozitívabb iskolai viszony figyelhetö meg (Evers és mtsai, 2004).

Továbbá egyetemi hallgatókkal végzett kutatások azt is bizonyították, hogy a magasabb észlelt tanári kiégés együtt jár a csalás nagyobb mértékü elfogadásával is (Orosz és Karsai, 2012).

Emellett középiskolások körében a tanárok kiégésének és az osztálytársak normáinak észlelése is összefüggést mutat. A diákok osztálytársaik körében elfogadóbb attitüdöt feltételeznek a negatív viselkedések, például órai rendbontások iránt, ha a tanáraik észlelt kiégése magasabb (Jagodics és mtsai, 2020). Ez az összefüggés megjelenik a magatartási problémák gyakoriságával kapcsolatban is. Ennek hátterében két egymást erösítő folyamat állhat. Egyrészt a rendbontó viselkedés csökkentheti a pedagógusok motivációját, lelkesedését, énhatékonyság-érzését (Aldrup és mtsai, 2018; Friedman, 1995), amit a 
diákok is észlelnek. Másrészt a tanárok észlelt érdektelensége növelheti a rendbontó viselkedések gyakoriságát azáltal, hogy a diákok figyelmét nem köti le a tanóra. A két, egymást erősítő folyamat pedig létrehozhat egyfajta ördögi kört, amely mind a pedagógusok, mind a tanulók számára kedvezőtlen iskolai környezetet eredményez. Ezeknek a hatásmechanizmusoknak a mélyebb megértése érdekében fontos minél pontosabban feltárni a normák és az észlelt tanári kiégés kapcsolatát, elsősorban egyetemisták esetében, akikkel kapcsolatban még nem készült hasonló vizsgálat.

\section{A tanulási motiváció célorientációs elmélete}

Az iskolai motivációk feltárása a neveléstudományi fókuszú kutatások egyik központi témája. Ennek megfelelően számos különböző motivációelmélettel találkozhatunk, legygyakrabban a külső-belső motiváció dimenzióját használó öndeterminációs elmélettel (Deci és Ryan, 1985, 2000), valamint a célorientációs modellel. Kutatásunkban a célorientációs elméletet alkalmaztuk, mert társas beágyazottsága miatt kapcsolódik a vizsgálat szociális kontextusú fókuszához. A célorientációs elmélet (Dweck és Leggett, 1988; Elliot és mtsai, 1999; Elliot és Murayama, 2008) két dimenzió mentén határozza meg a tanulási helyzethez füződő motivációkat. Az egyik dimenzió az elsajátító és a viszonyító célok végpontjai adják. Az elsajátító célok a készségek fejlesztésére, a teljesítmény növelésére irányulnak, míg a viszonyító célok a társas környezethez képest határozzák meg a sikert, vagyis az osztály- vagy évfolyamtársak teljesítménye a mérce a siker vagy a kudarc meghatározásakor. A másik dimenziót a közelítő és az elkerülő célok jelentik. A közelítő célkitüzések a lehető legjobb, fejlődést jelentő teljesítmény elérését jelenítik meg, míg a másik végpont esetében a cél a kudarccal, sikertelenséggel járó tapasztalatok elkerülése.

A vizsgálatok szerint a viszonyító célkitüzések a tananyag felszínesebb feldolgozásával járnak együtt (Elliot és mtsai, 1999), míg az elsajátítási célok a jobb tanulmányi eredménnyel és a magasabb tanulmányi elköteleződéssel mutatnak összefüggést (Duchesne és Larose, 2018; Putwain és mtsai, 2018). A magyar mintán végzett felmérések szerint a hazai viszonyok kulturális sajátosságának tekinthető, hogy a Célorientációs Kérdöív adaptációjában nem különül el az eredeti négy alskála a két dimenzió mentén (Pajor, 2013). A viszonyító típusú célok ugyanis nem differenciálhatók a közelítő és elkerülő sajátosságok mentén. Ugyanakkor a közelítő-elsajátító célok és a tanulmányi teljesítmény együtt járását a hazai vizsgálatok is megerősítették (Pajor, 2013; Pajor Gabriella, 2015). A célorientációs típusok és a csoportnormák kapcsolatait feltáró korábbi vizsgálatok eredményei szerint mindhárom célorientációs típus pozitív összefüggést mutat a pozitív viselkedésekhez füződő személyes normákkal, és negatív kapcsolatban állnak a rendbontó viselkedésekhez füződő attitüddel. Az elöíró normák esetében hasonló összefüggések figyelhetők meg: az osztálytársaknak tulajdonított elfogadó attitüd a negatív viselkedések esetében fordított együtt járást mutat a közelítő-elsajátító motivációkkal, míg a pozitív viselkedések esetében az erősebb célorientáció jelenik meg (Gajdics és mtsai, 2020). Ez arra utal, hogy a célorientáció nem független a társas környezettől, a kortársaktól látott viselkedéstől, illetve a nekik tulajdonított attitüdtől.

\section{A normák, a motiváció és az észlelt tanári kiégés kapcsolata}

A kutatás három fö eleme, vagyis a csoport normarendszere, illetve a tanulókra jellemző célorientációs stílus és a tanárok észlelt kiégése kölcsönösen kapcsolódó tényezők. A tanári viselkedés és kommunikáció kapcsolata a tanulók motivációjával sokat kutatott terület. Azok a diákok, akik tanáraikat gyakran látják elégedetlennek és szigorúnak, 
alacsonyabb motivációról számolnak be (Shukla, Kuril és Chand, 2020). Ezzel ellentétben azok a diákok, akik tanáraikat lelkesnek és energikusnak észlelik, magasabb belső motivációval jellemezhetők, és hajlamosabbak az elsajátítási célok kitűzésére (Lazarides, Buchholz és Rubach, 2018).

Egy korábbi magyar kutatás eredményei szerint a pedagógusok észlelt kiégése, illetve a diákok motivációja egyaránt kapcsolatot mutat az osztály normarendszerével. Középiskolás osztályközösségek vizsgálata szerint a közelítő-elsajátító célorientáció közepesen erős együttjárást mutat a pozitív viselkedésekre vonatkozó személyes, leíró és előíró normákkal is (Gajdics és mtsai, 2020.) Az észlelt tanári kiégés esetében ezzel ellentétes irányú kapcsolat mutatkozik meg: a pozitív viselkedések gyakorisága és elfogadottsága fordított együtt járást mutat az észlelt tanári kiégéssel, míg a negatív magatartásformák az alacsonyabb észlelt tanári lelkesedéshez kapcsolódnak (Gajdics és mtsai, 2020). Ezek az eredmények megerösítik, hogy az egyéni motiváció kialakulására mind a pedagógusok, mind pedig az osztálytársak viselkedése jelentős hatást gyakorolhat társas faktorként.

\section{A kutatás célkitüzései, hipotézisei}

A kutatásunk célja az volt, hogy feltárjuk az egyetemi hallgatók tanulási helyzetekkel kapcsolatos leíró, személyes és elöíró normáit. Ez egyrészt lehetővé teszi, hogy képet alkothassunk arról, hogy hogyan észlelik az egyetemisták a közösségükben gyakorinak számító viselkedéseket. Másrészt a személyes és elöíró normák közötti kapcsolat alapján feltárható, hogy a viselkedések észlelése során megjelenik-e a többszörös tudatlanság jelensége. Emellett célunk volt feltárni a normák kapcsolatát az észlelt tanári kiégéssel és a hallgatók motivációjának célorientációs jellemzőivel.

Feltételeztük, hogy a középiskolás korcsoportokban végzett vizsgálatokhoz hasonlóan egyetemi hallgatói mintán is azonosítható a többszörös tudatlanság jelensége (Jagodics és Szabó, 2019; Kóródi és mtsai, 2020; O’Gorman, 1986; Shelton és Richeson, 2005; Szabó és Labancz, 2015). Ennek megfelelően azt vártuk, hogy az egyes viselkedésekhez kapcsolódó személyes megítélés és az előíró normák között jelentős különbséget találunk (H1). Ennek részeként azt vártuk, hogy a pozitív viselkedések esetében a személyes attitüd pozitívabb lesz, mint a csoportnak tulajdonított, míg a negatív magatartásformáknál a csoportnak tulajdonított egyetértés lesz nagyobb a személyes elfogadásnál. A normavizsgálattal kapcsolatban továbbá feltételeztük, hogy a korábbi vizsgálatoknak megfelelően nem lesz nemi különbség a személyes normákat tekintve (H2; Gajdics és mtsai, 2020).

A célorientációs jellemzőkkel kapcsolatban feltételeztük, hogy a pozitív tartalmú viselkedések együtt járnak a közelítő célorientációval (H3; Gajdics és mtsai, 2020). Az észlelt tanári kiégés esetében pozitív együtt járást vártunk a negatív viselkedésekkel, míg fordított kapcsolatot feltételeztünk a pozitív magatartásformákkal (H4; Gajdics és mtsai, 2020).

\section{Módszerek}

\section{Résztvevők}

A vizsgálatban 337 fő (279 nő és 57 férfi; 1 válasz nélkül; átlagéletkor: 23,4 év, szórás: 5,18 év) vett részt. A résztvevők 19\%-a első, 23,7\%-a második, 27,3\%-a harmadik évfolyamos. 14,5\%-uk osztatlan képzés negyedévében, vagy mesterképzés első évében tanul, 11,9\%-uk pedig osztatlan képzésben ötöd-, illetve mesterképzésben másodéves. A résztvevők 3,6\%-a hatodévesként jelölte meg évfolyamát. Finanszírozási formát tekintve a kitöltők közül 248-an államilag támogatott, míg 89-en önköltséges képzésben tanultak. 


\section{Méröeszközök}

Normavizsgálat

A normákat vizsgáló kérdőívet Szabó és Labancz (2015) módszere alapján állítottuk össze. A vizsgálat középpontjában egy viselkedéslista áll, amelyeket a csoportban várhatóan előforduló és a csoport múködése szempontjából releváns területek alapján állítunk össze. A viselkedéseket három szempont alapján értékelik a válaszadók: megjelölik észlelt gyakoriságukat (leíró normák), saját véleményüket a viselkedésekről (személyes normák), illetve azt, hogy milyen vélekedéseket tulajdonítanak a többi csoporttagnak (elöíró normák). Tekintettel arra, hogy hallgatók esetében még nem készült felmérés ezzel a módszerrel, egy középiskolások körében korábban már használt viselkedéslistát alakítottunk át úgy, hogy illeszkedjen az egyetemi környezethez (Jagodics és Szabó, 2019). A tételekre négyfokozatú Likert-skálán válaszolnak a kitöltők. A vizsgálatban használt tételeket az 1. táblázat tartalmazza.

\section{Észlelt Tanári Kiégés Kérdőív}

Az oktatók kiégésének mérésére az Észlelt Tanári Kiégés Kérdőívet használtuk (Jagodics és mtsai, 2020). A kérdőív eredetileg középiskolás diákoknak szól, ezért a tételek tartalmát igazítottuk az egyetemi környezethez, például a „tanár” szó helyett az „oktatót” használtuk. A kérdőív 10 tételből áll, amelyek két alskálát alkotnak: az észlelt tanári kiégést és a fordított tételekből álló észlelt tanári lelkesedést. Jelen vizsgálatban a két alskálát összesítve használjuk, egyetlen pontszámként kezelve az észlelt tanári kiégést. A tételekre a kérdőív kitöltése során négyfokozatú Likert-skálán válaszolnak a résztvevők (1 - Soha; 4 - Mindig). Az alskálák és a teljes skála belső reliabilitása elfogadhatónak, illetve jónak mondható a Cronbach $\alpha$ értékek alapján: észlelt tanári kiégés (Cronbach $\alpha=0,664$ ), észlelt oktatói lelkesedés (Cronbach $\alpha=0,865$ ), teljes skála (Cronbach $\alpha=0,829)$.

\section{Célorientációs Kérdőív}

A célorientációs kérdőív egy 20 tételből álló mérőeszköz (Pajor, 2013). A kérdőív tételei három alskálát alkotnak: viszonyító, elkerülő-elsajátító és közelítő-elsajátító célorientációt különítenek el. A tételeket ötfokozatú Likert-skálán válaszolják meg a kitöltők (1 - Egyáltalán nem jellemző; 5 - Teljes mértékben jellemző). Az alskálák megbízhatósága jónak bizonyult a Cronbach $\alpha$ mutatók alapján: viszonyító célorientáció (Cronbach $\alpha=0,882$ ), elkerülö-elsajátító célorientáció (Cronbach $\alpha=0,756$ ), illetve közelítőelsajátító célorientáció (Cronbach $\alpha=0.78$ ).

\section{Eljárás}

Az adatfelvétel online környezetben, anonim módon történt 2020 őszén. A résztvevőket hozzáférési mintavétellel, egyetemi levelezőlistákon és csoportokon keresztül toboroztuk. A résztvevők szabadon dönthettek az adatfelvétel megkezdéséröl. Ellenszolgáltatásban egyik kitöltő sem részesült. A kérdőív megkezdése előtt a résztvevők tájékoztató szöveget olvastak a vizsgálat céljáról, módszereiről, az adatfelvétel körülményeiről és arról, hogy jogukban áll bármikor megszakítani a kitöltést. A kutatás módszereit az adatfelvétel megkezdése előtt engedélyezte az Egyesített Pszichológiai Kutatásetikai Bizottság (EPKEB). Az engedély referenciaszáma: 2020-91. 


\section{Eredmények}

\section{A normavizsgálat elemzése: gyakori viselkedések és a többszörös tudatlanság}

A statisztikai elemzés során elsőként ellenőriztük, hogy a normavizsgálatban a résztvevők minden viselkedés esetében relevánsnak észlelik-e az adott magatartásformát. Ehhez a leíró normákat, vagyis az észlelt gyakoriságot elemeztük. Az adatok szerint összesen öt olyan viselkedéses tétel szerepelt, ahol a válaszadók több mint kétharmada úgy nyilatkozott, hogy „,soha” nem fordulnak elő az adott viselkedések. Ezeket a tételeket a későbbi faktorelemzésből kihagytuk, mert nem tekinthetőek a normák szempontjából relevánsnak, ha a csoport döntö többsége szerint nem jelennek meg az adott kontextusban. Ezek a viselkedések a következők voltak: „6. más nevében vizsgázik vagy vesz részt számonkérésen.”; „10. gúnyos megjegyzést tesz a jól teljesítő hallgatókra” „16. viselkedésével zavarja a tanórát.” „18. gúnyos megjegyzést tesz a rosszul teljesítő hallgatókra.” „22. Más munkáját adja be sajátjaként (internetről, korábbi hallgatói dolgozat)”.

A leíró normákkal kapcsolatos adatok elemzése rámutatott arra, hogy a résztvevők alapvetően pozitív és proszociális viselkedéseket értékeltek leggyakrabban előfordulóként. A szabályellenes viselkedések közül a tanórákon történő mobiltelefon-használat volt a leggyakoribb. Az adatok részletesen az 1. táblázat tartalmazza.

Ezt követően a többszörös tudatlanság megjelenésére vonatkozó hipotézist (H1) teszteltük. Tekintettel arra, hogy az egyes magatartásformákhoz füződő személyes és előíró normák változóinál nem teljesült a normáleloszlás a Saphiro-Wilk-próba alapján $(\mathrm{p}<0,05)$, nem-paraméteres Wilcoxon-próbával hasonlítottuk össze az átlagokat. Az eredmények szerint a 23 viselkedés közül 22 esetében szignifikáns különbség található a személyes és az előíró normák között $(\mathrm{p}<0,05)$. Egyedül a „Megosztja másokkal az egyetemi információkat" tétel esetében nem tért el jelentősen a két átlag $(p=0,41)$. A leíró statisztikai adatokat, illetve a próbák eredményeit részletesen az 1. táblázat tartalmazza. Érdekes eredmény, hogy az alacsony gyakoriságuk miatt korábban megjelölt öt tétel esetében is megfigyelhető a többszörös tudatlanság, vagyis annak ellenére magasabb egyetértést tulajdonítottak ezeknek a negatív viselkedéseknek a kitöltők, hogy saját élményeik alapján alacsonynak észlelik az előfordulásukat.

Az átlagok összehasonlításából látható, hogy a személyes és elöíró normák közötti különbségek jellemző tendenciát követnek. A pozitív viselkedések, vagyis a proszociális magatartásformákra és az egyetemi szabályok betartására vonatkozó tételek esetében a személyes normák átlaga támogatóbb hozzáállásról tanúskodik, mint a többi hallgatónak tulajdonított attitüd esetében. A negatív viselkedések, vagyis a szabályszegéssel, illetve az egyetemi munkához való hanyag hozzáállással kapcsolatos tételek esetében pedig ezzel ellentétes irányú eltérést tárt fel az elemzés. A negatív viselkedések esetében a résztvevők a többi hallgatónak erősebb egyetértést tulajdonítottak, mint amennyire saját maguk egyetértettek a magatartásokkal. Ezek a különbségek megerősítik a hipotézis $(\mathrm{H} 1)$ feltételezéseit. 
1. táblázat: A leíró, személyes és elöiró normákhoz tartozó legfontosabb leiró statisztikai adatok. A többszörös tudatlanság megjelenését ellenörzö Wilcoxon-próba eredményei a személyes és az elöiró normák közötti különbségre utalnak. *p $<0,05 ; * * p<0,001$.

\begin{tabular}{|c|c|c|c|c|c|c|c|}
\hline & \multicolumn{2}{|c|}{ Leíró normák } & \multicolumn{2}{|c|}{$\begin{array}{l}\text { Személyes } \\
\text { normák }\end{array}$} & \multicolumn{2}{|c|}{ Elöíró normák } & \multirow{2}{*}{$\begin{array}{c}\text { Többszörös } \\
\text { tudatlanság } \\
\text { Wilcoxon- } \\
\text { próba }\end{array}$} \\
\hline & Átlag & Szórás & Átlag & Szórás & Átlag & Szórás & \\
\hline $\begin{array}{l}\text { Részt vesz a kötelező órákon } \\
\text { (gyakorlat, szeminárium, stb.). }\end{array}$ & 3,72 & 0,541 & 3,87 & 0,405 & 3,63 & 0,56 & $4926^{* *}$ \\
\hline $\begin{array}{l}\text { Az egyetemi órán vagy gyakorlat } \\
\text { közben a mobiltelefonját } \\
\text { használja (nem órai feladat } \\
\text { megoldásával kapcsolatban). }\end{array}$ & 2,76 & 0,796 & 2,07 & 0,549 & 2,39 & 0,682 & $720 * *$ \\
\hline $\begin{array}{l}\text { Részt vesz a nem kötelező órákon } \\
\text { (pl. előadás). }\end{array}$ & 2,95 & 0,76 & 3,51 & 0,594 & 3,18 & 0,664 & $9342 * *$ \\
\hline Aláírja más helyett a jelenléti ívet. & 1,63 & 0,766 & 1,91 & 0,806 & 2,4 & 0,792 & $1614 * *$ \\
\hline $\begin{array}{l}\text { Kérdést tesz fel az oktatónak a } \\
\text { tananyaggal kapcsolatban. }\end{array}$ & 2,59 & 0,848 & 3,57 & 0,604 & 3,24 & 0,715 & $8672 * *$ \\
\hline Ötösre vizsgázik. & 2,98 & 0,788 & 3,85 & 0,415 & 3,67 & 0,512 & $2238^{* *}$ \\
\hline $\begin{array}{l}\text { Nem vesz részt kellöképpen a } \\
\text { csoportos feladat, projektmunka } \\
\text { megoldásában. }\end{array}$ & 1,98 & 0,803 & 1,41 & 0,646 & 1,68 & 0,8 & $1763^{* *}$ \\
\hline $\begin{array}{l}\text { Kölcsönadja a többieknek a } \\
\text { jegyzeteit. }\end{array}$ & 3,15 & 0,781 & 3,62 & 0,534 & 3,72 & 0,553 & $2049 *$ \\
\hline $\begin{array}{l}\text { Megosztja az évfolyamtársakkal a } \\
\text { vizsgakérdéseket. }\end{array}$ & 2,98 & 0,871 & 3,34 & 0,721 & 3,64 & 0,597 & $2258^{* *}$ \\
\hline Puskázik a vizsgán. & 2,15 & 0,777 & 1,81 & 0,694 & 2,24 & 0,768 & $820 * *$ \\
\hline $\begin{array}{l}\text { Jelentkezik, ha az oktató kérdez } \\
\text { valamit. }\end{array}$ & 2,47 & 0,813 & 3,5 & 0,609 & 3,23 & 0,72 & $5916^{* *}$ \\
\hline $\begin{array}{l}\text { Engedély nélkül dolgozik össze } \\
\text { más hallgatókkal a vizsgán. }\end{array}$ & 1,9 & 0,729 & 1,87 & 0,704 & 2,27 & 0,804 & $1089^{* *}$ \\
\hline $\begin{array}{l}\text { Elindul egy tanulmányi versenyen } \\
\text { (pl. TDK, OTDK). }\end{array}$ & 1,76 & 0,772 & 3,58 & 0,689 & 3,44 & 0,722 & $2827 * *$ \\
\hline $\begin{array}{l}\text { Megosztja másokkal az egyetemi } \\
\text { képzéssel kapcsolatos } \\
\text { információkat. }\end{array}$ & 3,24 & 0,747 & 3,81 & 0,5 & 3,79 & 0,497 & 773 \\
\hline $\begin{array}{l}\text { Kiveszi a részét a } \\
\text { csoportmunkából is. }\end{array}$ & 3,28 & 0,615 & 3,81 & 0,475 & 3,67 & 0,564 & $757 * *$ \\
\hline $\begin{array}{l}\text { Hangoztatja, hogy a célja a kettes } \\
\text { jegy megszerzése. }\end{array}$ & 2,15 & 0,885 & 2,09 & 0,67 & 2,49 & 0,752 & $1007^{* *}$ \\
\hline $\begin{array}{l}\text { Elmegy bulizni hétköznap akkor } \\
\text { is, ha másnap órája vagy } \\
\text { vizsgája lesz. }\end{array}$ & 2,31 & 0,946 & 2,07 & 0,736 & 2,61 & 0,77 & $1600^{* *}$ \\
\hline
\end{tabular}




\begin{tabular}{|c|c|c|c|c|c|c|c|}
\hline & \multicolumn{2}{|c|}{ Leíró normák } & \multicolumn{2}{|c|}{$\begin{array}{l}\text { Személyes } \\
\text { normák }\end{array}$} & \multicolumn{2}{|c|}{ Előíró normák } & \multirow{2}{*}{$\begin{array}{c}\text { Többszörös } \\
\text { tudatlanság } \\
\text { Wilcoxon- } \\
\text { próba }\end{array}$} \\
\hline & Átlag & Szórás & Átlag & Szórás & Átlag & Szórás & \\
\hline $\begin{array}{l}\text { Erőteljes véleményt fogalmaz } \\
\text { meg egy oktató tudásával, } \\
\text { személyiségével vagy } \\
\text { módszereivel kapcsolatban. }\end{array}$ & 2,26 & 0,858 & 2,06 & 0,77 & 2,32 & 0,825 & $2444 * *$ \\
\hline $\begin{array}{l}\text { Más nevében vizsgázik vagy vesz } \\
\text { részt számonkérésen. }\end{array}$ & 1,08 & 0,346 & 1,19 & 0,467 & 1,47 & 0,684 & $429 * *$ \\
\hline $\begin{array}{l}\text { Gúnyos megjegyzést tesz a jól } \\
\text { teljesító hallgatókra. }\end{array}$ & 1,32 & 0,582 & 1,16 & 0,449 & 1,56 & 0,683 & $490 * *$ \\
\hline Viselkedésével zavarja a tanórát. & 1,33 & 0,554 & 1,12 & 0,34 & 1,37 & 0,546 & $653 * *$ \\
\hline $\begin{array}{l}\text { Gúnyos megjegyzést tesz a } \\
\text { rosszul teljesítő hallgatókra. }\end{array}$ & 1,31 & 0,594 & 1,15 & 0,414 & 1,46 & 0,663 & $431 * *$ \\
\hline $\begin{array}{l}\text { Más munkáját adja be sajátjaként } \\
\text { (internetről, korábbi hallgatói } \\
\text { dolgozat). }\end{array}$ & 1,29 & 0,526 & 1,18 & 0,474 & 1,51 & 0,694 & $308^{* *}$ \\
\hline
\end{tabular}

\section{A leíró, a személyes és az elöiró normák szerkezetének elemzése}

Az elemzés második lépéseként feltáró faktorelemzés segítségével vizsgáltuk meg, hogy a 18 viselkedés megítélésére jellemző-e valamilyen struktúra. Az elemzéseket a leíró, a személyes és az elöíró normák esetében egyaránt elvégeztük. A faktorelemzést maximum likelihood módszerrel és Oblimin-forgatással végeztük el. Az elemzés során a faktorok számát párhuzamos elemzéssel határoztuk meg (Horn, 1965), vagyis nem kezeltük követelményként, hogy a faktorok sajátértéke mindenképpen meghaladja az 1-es értéket. Az elemzéskor a 0,3-es értéket határoztunk meg az egyes tételek minimum faktortöltésének határértékeként (Samuels, 2016). Emellett pedig kritérium volt, hogy egy item töltése egyszerre több faktoron ne haladja meg ezt az értéket. Az elemzés során arra törekedtünk, hogy mindhárom szempont esetében egységes faktorokat kaphassunk. Emiatt a tételek besorolása során megengedően kezeltük, ha egy-egy item esetében az egyik szempont esetében alacsony faktortöltést tárt fel az elemzés, vagy több faktor esetében is 0,3 -es értéket meghaladó töltéssel találkoztunk. A faktorelemzések eredményeit az 1. táblázat foglalja össze.

A leíró normák esetében a Kaiser-Meyer-Olkin-mutató $(\mathrm{KMO}=0,781)$ és a Bartlettféle teszt $(\mathrm{p}<0,001)$ egyaránt megerösítette, hogy a változók alkalmasak a faktorelemzésre. Az elemzés három faktorból álló struktúrát tárt fel, melyben mind a 18 tétel legalább 0,334-es töltéssel tartozott valamelyik faktorhoz. Két tétel (3. és 19.) esetében okozott problémát, hogy egyszerre két faktor esetében is hasonlóan magas faktortöltést tárt fel az elemzés. Az elemzés alapján az első faktorba a negatív, egyetemi szabályokkal ellentétes viselkedések tartoztak, a másodikba pedig a pozitív, szabályokkal egyező magatartásformák. A harmadik faktort négy, együttmüködésre és a társak segítésére vonatkozó proszociális viselkedés alkotta.

A személyes normák esetében a Kaiser-Meyer-Olkin-mutató $(\mathrm{KMO}=0,804)$ és a Bartlett-féle teszt $(\mathrm{p}<0,001)$ egyaránt megerősítette, hogy a változók alkalmasak 
a faktorelemzésre. Az elemzés három faktorból álló struktúrát tárt fel, melyben két tétel (1. és 23.) kivételével mindegyik viselkedés legalább 0,339-es töltéssel tartozott valamelyik faktorhoz. A faktorok tartalma hasonlóan alakult, mint a leíró normák esetében: a negatív és pozitív viselkedésekre utaló viselkedések mellett megjelent a proszociális magatartásformákat magába foglaló faktor is, de ebben az esetben négy helyett csak két tétel tartozott hozzá.

Az elöíró normák esetében a Kaiser-Meyer-Olkin-mutató $(\mathrm{KMO}=0,837)$ és a Bartlett-féle teszt $(\mathrm{p}<0,001)$ egyaránt megerősítette, hogy a változók alkalmasak a faktorelemzésre. Az elemzés három faktorból álló struktúrát tárt fel, melyben egy tétel (8.) esetében volt kimutatható elégséges mértékü töltés egyik faktorra sem. Emellett a 15. tétel egyszerre két faktorra is erös töltést mutatott. A faktorok tartalma hasonlóan értelmezhető, mint a leíró és a személyes normák esetében: a tételek elrendeződése a pozitív, a negatív és a proszociális viselkedések elkülönülésére utaltak.

A három elemzés tehát szinte teljesen azonos struktúrát tárt fel a különböző normaszempontok esetében. Eltérés egy-egy tétel esetében volt megfigyelhető, illetve változást mutatott, hogy melyik faktor milyen súllyal jelenik meg összességében a megmagyarázott variancia tekintetében. Az elemzés alapján két tételt (1. és 8.) egyik faktorba sem soroltunk be, mert nem lehetett egyértelmüen besorolni őket egyik faktorba sem az elemzések alapján. További két tétel esetében (3., 15. és 19.) kérdéses volt, hogy melyik faktorba illeszkednek a legjobban. Mivel mindhárom tételnél egyezett két-két szempontnál, hogy melyik faktorhoz tartoznak, ez alapján soroltuk be őket végleges helyükre. Az eredmények alapján a 2. táblázatban is bemutatott felosztás szerint a továbbiakban a pozitív, a negatív és a proszociális normákat különböztettük meg.

\section{Nemi különbség a normák, a célorientáció és az észlelt tanári kiégés esetében}

Az elemzés következő lépéseként kiszámoltuk a faktorelemzés szerint megállapított normatípusok pontszámait a hozzájuk tartozó tételek átlagolásával. A pontszámok esetében szintén Shapiro-Wilk-próbával ellenöriztük a normáleloszlást, de mivel ez nem teljesült az újonnan létrehozott változók esetében $(\mathrm{p}<0,05)$, ezért a továbbiakban nemparametrikus statisztikai elemzéseket alkalmaztunk.

Ezt követően megvizsgáltuk a nemek közötti eltéréseket. Előfeltevésünkben (H2) nem számítottunk jelentős különbségre a férfiak és a nők pontszámai között a normavizsgálat esetében. Az elemzésekhez nem-parametrikus Mann-Whitney-tesztet alkalmaztunk. Az elemzés szerint három normatípus esetében található eltérés a férfiak és a nők átlagpontszámaiban. A személyes normák esetében a pozitív viselkedéseket szignifikáns mértékben $(U=6017 ; p=0,024$; Cohen-féle d-érték $=0,352)$ erősebben helyeslik a nők, mint a férfiak. A negatív viselkedéseknél ezzel ellentétes irányú az eltérés $(U=5620 ; p=0,011$; Cohen-féle d érték = -0,421): a férfiak elfogadóbbak, mint a nők. Az elöíró normatípusok esetében pedig a proszociális viselkedések észlelt elfogadottságában van nemi különbség $(\mathrm{U}=4792 ; \mathrm{p}=0,03$; Cohen-féle d érték =0,234): az eredmények szerint a nők erősebb egyetértést tulajdonítanak csoporttársaiknak a proszociális viselkedésekkel kapcsolatban, mint a férfiak. A leíró normák esetében nem tárt fel különbségeket a vizsgálat $(\mathrm{p}>0,05)$. A részletes eredményeket és a leíró statisztikai adatokat a 3. táblázat tartalmazza.

A célorientáció esetében a viszonyító céloknál nem tárt fel jelentős különbséget a MannWhitney-teszt. A közelítő-elsajátító $(U=6230 ; p=0,026$; Cohen-féle d érték $=0,417)$ és az elkerülö-elsajátító $(\mathrm{U}=5471 ; \mathrm{p}<0,001$; Cohen-féle $\mathrm{d}$ érték $=0,503)$ célok esetében pedig egyaránt a nőket jellemzi magasabb átlagpontszám. Az észlelt tanári kiégés esetében nem tárt fel statisztikailag jelentős különbséget a vizsgálat a nemek között $(p>0,05)$. A részletes eredményeket és a leíró statisztikai adatokat a 3. táblázat tartalmazza. 


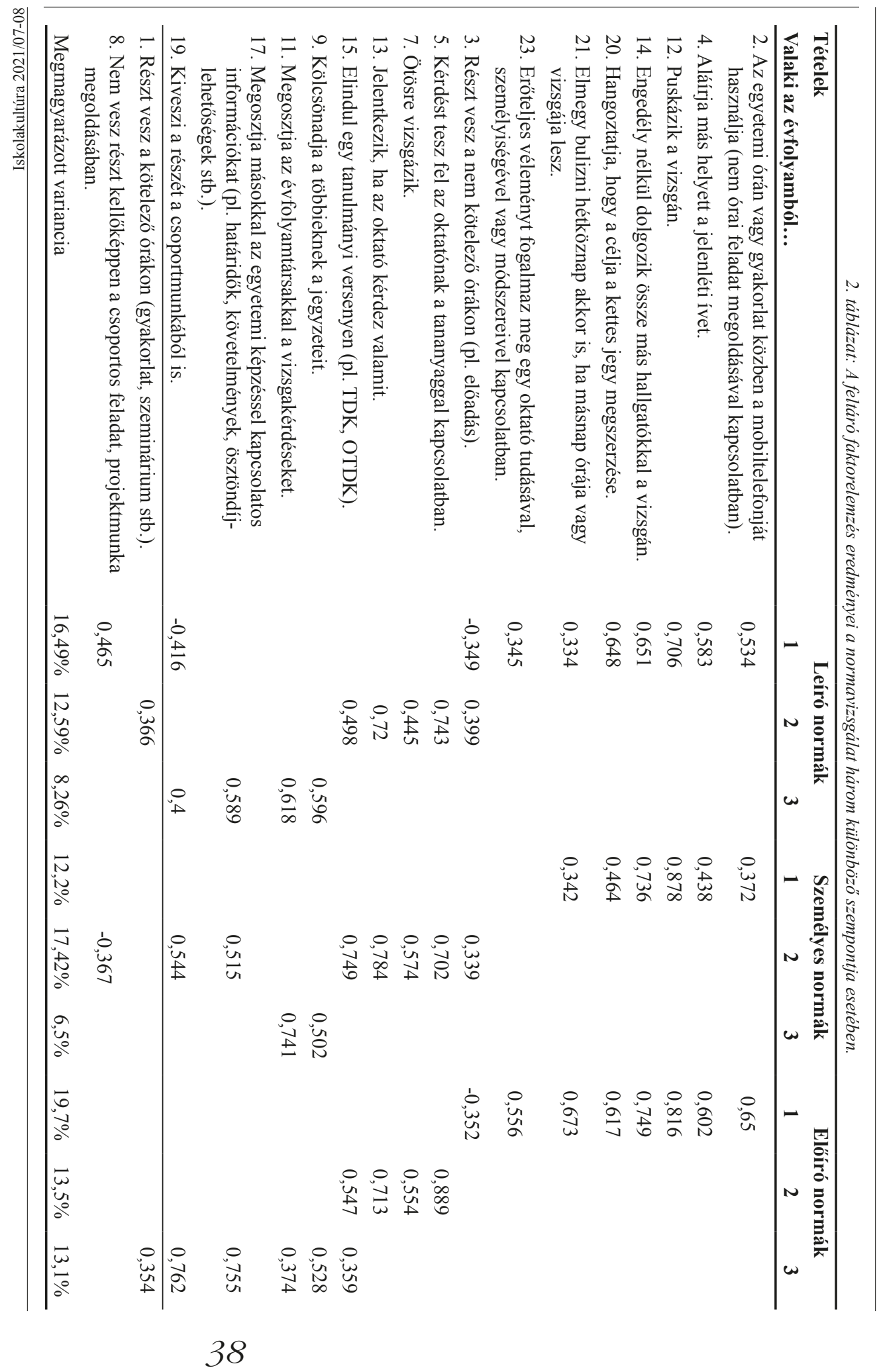


Jagodics Balázs - Szabó Éva: Egyetemi hallgatók normáinak összefüggése a motivációval és az észlelt oktatói kiégéssel

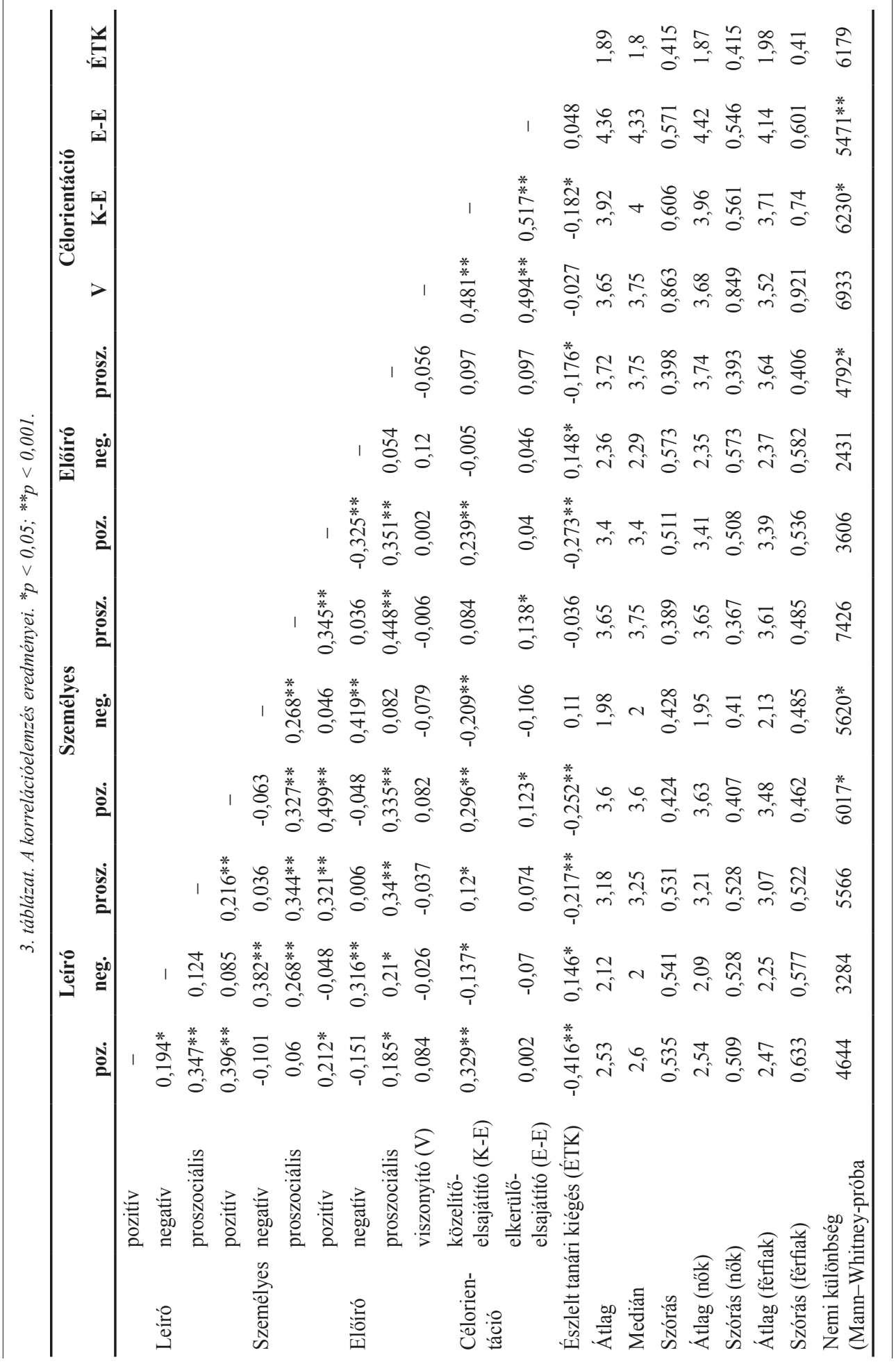




\section{A normák kapcsolata az észlelt tanári kiégéssel és a célorientációval}

Ezután Spearman-féle korrelációelemzéssel megvizsgáltuk a változók közötti összefüggéseket, kiegészítve az elemzést a célorientációs típusokkal és az észlelt tanári kiégéssel (H3 és H4). A korrelációelemzés eredményeit a 3. táblázat tartalmazza. Az eredmények szerint a személyes és az elöíró normák nem teljesen függetlenek egymástól. Mindhárom normatípus esetében közepes erősségü, szignifikáns pozitív kapcsolatot tárt fel az elemzés a saját attitüd és a többieknek tulajdonított vélekedés között.

A célorientációs típusok közül a viszonyító függetlennek bizonyult az összes normatípustól. A közelítő-elsajátító norma ezzel szemben gyenge, de szignifikáns pozitív együtt járást mutatott a pozitív viselkedésekhez kapcsolódó leíró és elöíró normákkal is. Ezek az eredmények részben megerősítették az előfeltevéseinket (H3).

Az észlelt tanári kiégés és a pozitív viselkedések észlelésének gyakorisága közepesen erős, negatív korreláció található. A többi normatípus esetében nem szignifikáns vagy gyenge kapcsolatok tárt fel az elemzés. A kapcsolatok iránya jellemző tendenciát követ. A negatív viselkedések összefüggenek az észlelt tanári kiégéssel, míg a pozitív és proszociális magatartások negatív együtt járást mutatnak az oktatók lelkesedésének hiányával. Ezek ez eredmények megerősítették az előfeltevéseket (H4).
A leíró normák szerint a csalásra és a többi hallgató zaklatására irányuló magatartásformák elófordulása elenyészó. Fiatalabb korosztályokban, tehát általános és középiskolás tanulók között végzett felmérések gyakoribb problémaként irják le a bullying elófordulását (Kóródi és mtsai, 2020; Siegler, 2020). Egyetemi hallgatók körében más felmérések szerint is ritkábbak a zaklatás okozta problémák: egy finn felmérés 5\%-ra teszi a zaklatott hallgatók önbevallás alapján megállapi-

tott arányát (Sinkkonen és mtsai, 2014). Azonban az online térben történó zaklatás, a cyberbullying ennél jóval gyakoribbnak túnik: egy görög vizsgálat szerint a hallgatók 54\%-a vett részt online zaklatásban valamilyen szerepkörben, zaklatóként, támogatóként vagy áldozatként (Kokkinos és mtsai, 2014).

\section{Megvitatás}

Kutatásunk fő célkitűzése az volt, hogy egyetemi hallgatók között vizsgáljuk meg a tanulási helyzetekhez füződő normák jellemzőit, illetve ezek kapcsolatát az észlelt tanári kiégéssel és a célorientációval.

A normavizsgálatra vonatkozó eredmények az eredeti huszonhárom viselkedés közül öt esetében mutattak alacsony észlelt gyakoriságot. A leíró normák szerint a csalásra és a többi hallgató zaklatására irányuló magatartásformák előfordulása elenyésző. Fiatalabb korosztályokban, tehát általános és középiskolás tanulók között végzett felmérések gyakoribb problémaként írják le a bullying előfordulását (Kóródi és mtsai, 2020; Siegler, 2020). Egyetemi hallgatók körében más felmérések szerint is ritkábbak a zaklatás okozta problémák: egy finn felmérés 5\%-ra teszi a zaklatott hallgatók önbevallás alapján megállapított arányát (Sinkkonen és mtsai, 2014). Azonban az online térben történő zaklatás, 
a cyberbullying ennél jóval gyakoribbnak tünik: egy görög vizsgálat szerint a hallgatók $54 \%$-a vett részt online zaklatásban valamilyen szerepkörben, zaklatóként, támogatóként vagy áldozatként (Kokkinos és mtsai, 2014). Ezek az eredmények összességében arra utalnak, hogy a normavizsgálatot érdemes lenne kiterjeszteni az online viselkedésekre is, mert minél elterjedtebbé válik az internetes oldalak használata, annál több érintettje lehet a problémának. Főleg, hogy a koronavírus-járvány miatt előtérbe került a távoktatás, ami az egyetemi hallgatók interakcióit is az online térbe tereli. A csalásra vonatkozó viselkedések teljes elutasítása (soha nem fordul elö) az empirikus tapasztalatok alapján valószínúleg csoportorientált elfogultság, egyfajta énvédő torzítás. Sajnos számos etikai bizottsági vizsgálat, illetve plágiumszürés hozott ilyen ügyekben pozitív eredményt. A diákok válaszait ebben az esetben valószínűleg erősen motiválta a társas kívánatosságnak való megfelelés. Emellett magyarázhatja a csalás alacsony észlelt szintjét, hogy ezek a tevékenységek a legtöbb esetben rejtve maradnak a hallgatótársak és az oktatók előtt egyaránt.

A leíró normák elemzése rámutatott arra is, hogy alapvetően a pozitív viselkedéseket és a proszociális megnyilvánulásokat észlelik leggyakrabban a hallgatók. Ezek az eredmények összességében pozitív egyetemi légkörre utalnak. Ugyanakkor a kérdőívben használt tételek között vannak különbségek abban, hogy milyen mértékben vehetö észre egy-egy viselkedés. Néhány magatartásforma, például az órai jelenlét könnyen azonosítható, míg más viselkedések esetében (pl. puskázás a vizsgán) nagyobb a bizonytalanság a gyakoriság megítélésben.

A többszörös tudatlanság jelenségének előfordulására vonatkozó hipotéziseinket alátámasztották az eredmények. Korábbi vizsgálatokhoz (Gajdics és mtsai, 2020; Kóródi és mtsai, 2020; Schroeder és Prentice, 1998; Shelton és Richeson, 2005; Szabó és Labancz, 2015) hasonló tendenciát tártak fel az adatok: a pozitív viselkedéseknél alul-, míg a negatív viselkedéseknél felülbecsülték évfolyamtársaik vélt elfogadását a résztvevők. Ez a konformitás jelensége (Asch, 1956) miatt okozhat problémát. Amennyiben a hallgatók feltételezései szerint az évfolyamtársak elutasítóbbak a proszociális viselkedésekkel kapcsolatban, és megengedőbbek a negatív megnyilvánulásokat illetően, az magában hordozza annak a veszélyét, hogy ezekhez a vélt normákhoz fognak igazodni. Ez potenciális rizikófaktort jelent még a kezdetekben elkötelezett és motivált hallgatók esetében is. A negatív viselkedésminták elterjedése általánosságban ronthatja a közösség
Amennyiben a hallgatók feltételezései szerint az évfolyamtársak elutasitóbbak a proszociális viselkedésekkel kapcsolatban, és megengedóbbek a negatív megnyilvánulásokat illetóen, az magában hordozza annak a veszélyét, hogy ezekhez a vélt normákhoz fognak igazodni. Ez potenciális rizikófaktort jelent még a kezdetekben elkötelezett és motivált hallgatók esetében is. A negatív viselkedésminták elterjedése általánosságban ronthatja a közösség légkörét, csökkentve az egyetemi közeg megtartó erejét. Illetve a kisebbségi befolyásolás

(Moscovici és mtsai, 1969;

Moscovici, 1977) jelensége miatt fontos figyelembe venni, hogy ezeknek a folyamatoknak a megjelenéséhez nem szükséges, hogy a többség egyetértsen a negativ viselkedésekkel, egy jól körülhatárolható, de a többiek számára észlelhetó kisebbség is elegendö lehet. 
légkörét, csökkentve az egyetemi közeg megtartó erejét. Illetve a kisebbségi befolyásolás (Moscovici és mtsai, 1969; Moscovici, 1977) jelensége miatt fontos figyelembe venni, hogy ezeknek a folyamatoknak a megjelenéséhez nem szükséges, hogy a többség egyetértsen a negatív viselkedésekkel, egy jól körülhatárolható, de a többiek számára észlelhető kisebbség is elegendő lehet. Például számíthat, hogy a nem kötelező kurzusokon milyen arányban jelennek meg a hallgatók, hiszen a teljes létszámhoz képest alacsony részvétel közvetítheti a negatív normák elfogadottságát a jelenlévő tanulóknak. Ezek a szociálpszichológiai hatások hozzájárulhatnak az elméleti bevezetőben is említett magas lemorzsolódási arányhoz (Lukács és Sebö, 2015; Varga, 2010). Ez a hatás különösen annak az eredménynek a fényében lehet fontos, hogy az alacsony gyakoriságuk ellenére bizonyos negatív viselkedések, például a zaklatásra vagy a csalásra vonatkozó tételek esetében is megjelent a többszörös tudatlanság. Ez arra utal, hogy a hallgatók még akkor is úgy gondolhatják, hogy a társaik egyetértenek bizonyos viselkedésekkel, ha ezek ritkán vagy egyáltalán nem fordulnak elő a környezetükben. Ebben szerepe lehet a korábban már említett énvédő mechanizmusoknak, például a jobb mint átlag hatásnak (Svenson, 1981), amely a társakhoz képest elönyös összehasonlítással növelheti az egyén önértékelését (Brown, 2012; Gibbons és McCoy, 1991).

A nemek közötti hasonlóságokra vonatkozó hipotézist nem támasztották alá az eredmények. A pozitív viselkedéseket a nők, a negatív magatartásformákat pedig a férfiak fogadják el nagyobb mértékben. Ez a különbség jelen van az elöíró normák észlelésénél is, a férfiak ugyanis alulbecsülik a nőkhöz képest az évfolyamtársak attitüdjét a proszociális normákat illetően. Az eltérés magyarázható a minta azon sajátosságával, hogy a nők esetében mind az elkerülö-elsajátító, mind a közelítö-elsajátító motiváció esetében magasabb pontszámot figyeltünk meg. Vagyis a mintán belül több változó mentén is különbséget találtunk a férfiak és a nők között, amelyek alapján utóbbiak motiváltabbnak tünnek a tanulmányi célok tekintetében, ezáltal érthető, hogy a pozitív és proszociális normákhoz való viszonyuk is egyetértőbb.

A normák, illetve a célorientációs típusok esetében a várt kapcsolatokat erősítették meg a korrelációelemzések. A közelítő-elsajátító célok összefüggést mutattak a pozitív viselkedésekkel mindhárom normatípus esetében. Ugyan a korrelációs együtthatók gyengék, az eredmények jelzik, hogy a személyes és a társaknak tulajdonított attitüd egyaránt kapcsolódik a közelítő típusú célokhoz. A jelenség hátterében álló folyamatok két irányban is elképzelhetőek. Az egyik esetben a közelítő-elsajátító motiváció közösségen belüli magasabb szintjéből eredeztethető, hogy a tanulók nagyobb mértékben értenek egyet a pozitív viselkedésekkel, vagyis a tanulást támogató magatartásformákkal. A kapcsolat azonban a másik irányban is elképzelhető. Ha a hallgatók azt látják, hogy a tudás megszerzése érdekében mások is aktívan erőfeszítést tesznek, és ezeket a törekvéseket elfogadottnak észlelik társaik körében is, akkor egyéni szinten is erősebben fejeződhet ki az elsajátítási motiváció. Utóbbi folyamatnak megfelelően az eredmények alapján feltételezhető, hogy a pozitív viselkedések elfogadottságának növelésével, illetve gyakoribbá tételével megerősíthetők lennének a közelítő-elsajátító céltípusok, amelyek a tanulmányi sikerességhez kapcsolódnak (Duchesne és Larose, 2018; Pajor, 2013, 2015).

Az észlelt tanári kiégés esetében szintén a hipotéziseknek megfelelő kapcsolatokat tártunk fel. A leíró normák esetében a pozitív viselkedések és az észlelt kiégés közötti fordított összefüggés magyarázható az elméleti bevezetőben is említett folyamatokkal. Egyrészt elképzelhető, hogy a pozitív viselkedések alacsony gyakorisága azt sugallja a tanárnak, hogy a hallgatók nem érdeklődnek eléggé a tárgya vagy az órája iránt, ami hosszabb távon negatív hatással lehet az oktató attitüdjére, csökkentheti motivációját és lelkesedését az adott csoporttal, évfolyammal való munka kapcsán. Másik oldalról azonban az oktató kedvetlensége, érdektelensége is beindíthatja a diákok érdeklődésének és elköteleződésének fokozatos csökkenését. Ezek a folyamatok egymástól függetlenül is 
elindulhatnak, ugyanakkor hatásuk össze is adódhat, ami egy öngerjesztő spirált válthat ki, amit elsősorban az oktató önreflexiója, illetve módszertani felkészültsége törhet meg. Kutatásunk nem bizonyítja, hogy az egyik tényező indukálja a másikat, de rámutat a tanári lelkesedés szintjének észlelése és a diákok viselkedése közötti kapcsolatra, amely dinamikus hatást gyakorolhat mindkét fél közérzetére és motivációjára is.

\section{Limitációk}

Tekintettel arra, hogy a mintavétel hozzáférési alapon történt, a résztvevők csoportja nem reprezentálja megfelelően a magyar egyetemisták közösségét. Ezt jelzi, hogy a résztvevőkre a képzési területek tekintetében is aránytalanság volt jellemzö, illetve részben ebből fakadóan a nemek aránya sem tükrözte megfelelően a férfiak és nők felsőoktatási részarányát. További lényeges korlátja az eredmények általánosíthatóságának, hogy a normák valódi hatása elsősorban funkcionális csoportokban, főként 20 fönél kisebb létszámú tartósan együttműködő csoportban nyilvánul meg. Az általunk vizsgált minta tagjai inkább egy közös kategóriába tartoznak, és valójában nem is feltétlenül ismerik egymást. Ugyanakkor a viselkedések egyértelmü csoportokba rendeződése és a többszörös tudatlanság jelenségének megjelenése arra enged következtetni, hogy a vizsgálat eredményei bizonyos mértékig leképezhetik az egyetemi csoportok sajátosságait, jóllehet az egyes konkrét közösségekben ezek a tendenciák lehetnek erőteljesebbek vagy gyengébbek, esetleg más mintázottságúak is.

A vizsgálat további korlátai közé tartozik a kutatási elrendezés korrelációs jellege, amely ugyan lehetővé teszi a változók közötti kapcsolatok azonosítását, erősségük és irányuk meghatározását, de az ok-okozati következtetések levonásához nem elégségesek, habár az elméleti háttér támpontjaival jól értelmezhetők. A statisztikai próbák megbízhatóságát csökkentette továbbá, hogy a normáleloszlás feltételének nem teljesülése okán csak nem-parametrikus eljárásokat alkalmaztunk.

\section{Kitekintés}

A felsorolt limitációk ellenére úttörő jellegü tanulmányunk hozzájárulhat ahhoz, hogy mélyebben megértsük az egyetemi hallgatókat érintő szociálpszichológiai hatásokat, és fontos lépést jelenthet az egyetemi hallgatók motivációját befolyásoló társas hatások feltárása felé. A vizsgálatok jó alkalmat kínálnak majd arra, hogy a normavizsgálat elemzéséből a gyakorisági mutatók miatt kihagyott tételek esetében ellenőrizzük, hogy valóban elvétve fordulnak-e elö, vagy a minta jellegzetességét tükrözték a leíró normák.

\section{Támogatás}

Jagodics Balázs a kutatás elvégzéséhez támogatásban részesült. A kutatás az Innovációs és Technológiai Minisztérium ÚNKP-20-3-II-PTE-512 kódszámú Új Nemzeti Kiválóság Programjának a Nemzeti Kutatási, Fejlesztési és Innovációs Alapból finanszírozott szakmai támogatásával készült.

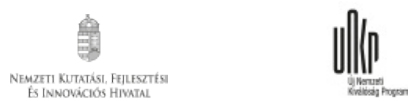




\section{Irodalom}

Aldrup, K., Klusmann, U., Lüdtke, O., Göllner, R. \& Trautwein, U. (2018). Student misbehavior and teacher well-being: Testing the mediating role of the teacher-student relationship. Learning and Instruction, 58, 126-136. DOI: 10.1016/j.learninstruc.2018.05.006

Asch, S. E. (1956). Studies of independence and conformity: A minority of one against a unanimous majority. Psychological Monographs: General and Applied, 70(9), 1-70. DOI: 10.1037/h0093718

Bjerring, J. C., Hansen, J. U. \& Pedersen, N. J. L. L. (2014). On the rationality of pluralistic ignorance. Synthese, 191(11), 2445-2470. DOI: 10.1007/s11229014-0434-1

Bottiani, J. H., Duran, C. A. K., Pas, E. T. \& Bradshaw, C. P. (2019). Teacher stress and burnout in urban middle schools: Associations with job demands, resources, and effective classroom practices. Journal of School Psychology, 77, 36-51. DOI: 10.1016/j.jsp.2019.10.002

Brown, J. D. (2012). Understanding the Better Than Average Effect: Motives (Still) Matter. Personality and Social Psychology Bulletin, 38(2), 209-219. DOI: $10.1177 / 0146167211432763$

Czakó Andrea, Németh Lilla \& Felvinczi Katalin (2019). A felsőfokú képzés befejezésére irányuló szándék előrejelzői. Educatio, 28(4), 718-736. DOI: 10.1556/2063.28.2019.4.5

Deci, E. L. \& Ryan, R. M. (1985). Intrinsic Motivation and Self-Determination in Human Behavior. Springer US. DOI: 10.1007/978-1-4899-2271-7

Deci, E. L. \& Ryan, R. M. (2000). The „What” and "Why" of Goal Pursuits: Human Needs and the Self-Determination of Behavior. Psychological Inquiry, 11(4), 227-268. DOI: 10.1207/ s15327965pli1104_01

Duchesne, S. \& Larose, S. (2018). Academic competence and achievement goals: Self-pressure and disruptive behaviors as mediators. Learning and Individual Differences, 68, 41-50. DOI: 10.1016/j. lindif.2018.09.008

Dweck, C. S. \& Leggett, E. L. (1988). A social-cognitive approach to motivation and personality. Psychological Review, 95(2), 256-273. DOI: 10.1037/0033$295 \times .95 .2 .256$

Elliot, A. J., McGregor, H. A. \& Gable, S. (1999). Achievement goals, study strategies, and exam performance: A mediational analysis. Journal of Educational Psychology, 91(3), 549-563. DOI: 10.1037/0022-0663.91.3.549

Elliot, A. J. \& Murayama, K. (2008). On the measurement of achievement goals: Critique, illustration, and application. Journal of Educational Psychology, 100(3), 613-628. DOI: 10.1037/0022-0663.100.3.613
Evers, W. J. G., Tomic, W. \& Brouwers, A. (2004) Burnout among Teachers: Students' and Teachers' Perceptions Compared. School Psychology International, 25(2), 131-148. DOI: 10.1177/0143034304043670

Feldman, D. C. (1984). The development and enforcement of groupnorms. Academy of Management Review, 9(1), 47-53. DOI: 10.5465/amr.1984.4277934

Fiske, S. T. (2004). Social beings: Core motives in social psychology. Wiley.

Friedman, I. A. (1995). Student Behavior Patterns Contributing to Teacher Burnout. The Journal of Educational Research, 88(5), 281-289. DOI: 10.1080/00220671.1995.9941312

Gajdics Janka, Gubics Flórián, Horvát Barbara, Vatai Katalin, Szabó Éva \& Jagodics Balázs (2020). Középiskolás osztályközösségek normarendszerének longitudinális vizsgálata: Az első két év eredményei. Iskolakultúra, 30(3), 18-34. DOI: 10.14232/ iskkult.2020.3.18

Geiger, N. \& Swim, J. K. (2016). Climate of silence: Pluralistic ignorance as a barrier to climate change discussion. Journal of Environmental Psychology, 47, 79-90. DOI: 10.1016/j.jenvp.2016.05.002

Gibbons, F. X. \& McCoy, S. B. (1991). Self-esteem, similarity, and reactions to active versus passive downward comparison. Journal of Personality and Social Psychology, 60(3), 414-424. DOI: 10.1037/0022-3514.60.3.414

Hakanen, J. J., Bakker, A. B. \& Schaufeli, W. B. (2006). Burnout and work engagement among teachers. Journal of School Psychology, 43(6), 495-513. DOI: 10.1016/j.jsp.2005.11.001

Halbesleben, J. R. B., Wheeler, A. R. \& Buckley, M. R. (2005). Everybody Else is Doing it, So Why Can't We? Pluralistic Ignorance and Business Ethics Education. Journal of Business Ethics, 56(4), 385-398. DOI: 10.1007/s10551-004-3897-z

Halbesleben, J. R. B., Wheeler, A. R. \& Buckley, M. R. (2007). Understanding pluralistic ignorance in organizations: Application and theory. Journal of Managerial Psychology, 22(1), 65-83. DOI: 10.1108/02683940710721947

Horn, J. L. (1965). A rationale and test for the number of factors in factor analysis. Psychometrika, 32, 179-185. DOI: 10.1007/bf02289447

Jagodics Balázs, Gajdics Janka, Gubics Flórián, Horvát Barbara, Vatai Katalin \& Szabó Éva (2020). Az Észlelt Tanári Kiégés Kérdőív szerkezetének vizsgálata középiskolás diákok körében. Iskolakultúra, 30(7), 46-60. DOI: 10.14232/iskkult.2020.7.46

Jagodics Balázs \& Szabó Éva (2019). Tipikus viselkedésformák és megítélésük feltárása középiskolás osztályközösségekben a normavizsgálat módszerével. 
Jagodics Balázs - Szabó Éva: Egyetemi hallgatók normáinak összefüggése a motivációval és az észlelt oktatói kiégéssel

Iskolakultúra, 29(8), 69-82. DOI: 10.14232/iskkult. 2019.8.3

Katz, D., Allport, F. H. \& Jennes, M. B. (1931). Students' attitudes; A report of the Syracuse University reaction study. Craftsman.

Kokkinos, C. M., Antoniadou, N. \& Markos, A. (2014). Cyber-bullying: An investigation of the psychological profile of university student participants. Journal of Applied Developmental Psychology, 35(3), 204-214. DOI: 10.1016/j.appdev.2014.04.001

Kóródi, K., Fürdök, F. \& Szabó, É. (2020). Iskolában elöforduló proszociális és agresszív viselkedések normavizsgálata. Iskolakultúra, 30(3), 50-61. DOI: 10.14232/iskkult.2020.3.50

Lackritz, J. R. (2004). Exploring burnout among university faculty: Incidence, performance, and demographic issues. Teaching and Teacher Education, 20(7), 713-729. DOI: 10.1016/j.tate.2004.07.002

Lambert, T. A., Kahn, A. S. \& Apple, K. J. (2003). Pluralistic ignorance and Hooking up. The Journal of Sex Research, 40(2), 129-133. DOI: $10.1080 / 00224490309552174$

Lazarides, R., Buchholz, J. \& Rubach, C. (2018). Teacher enthusiasm and self-efficacy, student-perceived mastery goal orientation, and student motivation in mathematics classrooms. Teaching and Teacher Education, 69, 1-10. DOI: 10.1016/j. tate.2017.08.017

Lukács Fruzsina \& Sebő Tamás (2015). Az egyetemi lemorzsolódás kérdőíves vizsgálata. Iskolakultúra, 25(10), 78-86. DOI: 10.17543/iskkult.2015.10.78

Maslach, C. \& Leiter, M. (1999). Teacher burnout: A research agenda. In Understanding and Preventing Teacher Burnout. Cambridge University Press. 295-303. DOI: 10.1017/cbo9780511527784.021

Moscovici, S., Lage, E. \& Naffrechoux, M. (1969). Influence of a Consistent Minority on the Responses of a Majority in a Color Perception Task. Sociometry, 32(4), 365. DOI: $10.2307 / 2786541$

Moscovici, S. (1977). Social influence and social change. Academic Press.

O'Gorman, H. J. (1986). The discovery of pluralistic ignorance: An ironic lesson. Journal of the History of the Behavioral Sciences, 22(4), 333-347. DOI: $10.1002 / 1520-6696(198610) 22: 4<333$ ::aidjhbs2300220405>3.0.co;2-x

Orosz Gábor \& Karsai Nóra Fruzsina (2012). Az egyetemi oktatók lelkesedésének és a hallgatók csalásának összefüggései. Iskolakultúra, 12(9), 3-11.

Pajor Gabriella (2013). Serdülök teljesítménymotivációja a célorientációs elmélet tükrében. $P h D$ disszertáció. ELTE Pedagógiai és Pszichológiai Kar, Budapest. http://pszichologia.phd.elte.hu/vedesek/ PAJOR GABRIELLA disszertacio.pdf
Pajor Gabriella. (2015). „, Gyorsabban, magasabbra, bátrabban" - de hogyan? Teljesitménymotiváció iskolai környezetben. ELTE Eötvös Kiadó.

Prentice, D. A. \& Miller, D. T. (1996). Pluralistic Ignorance and the Perpetuation of Social Norms by Unwitting Actors. In Advances in Experimental Social Psychology. 28. kötet. Elsevier. 161-209. DOI: 10.1016/s0065-2601(08)60238-5

Pusztai Gabriella, Kovács Klára \& Hegedűs Roland (2019). Lemorzsolódók tegnap, ma és holnap. Educatio, 28(4), 737-754. DOI: 10.1556/2063.28.2019.4.6

Putwain, D. W., Symes, W., Nicholson, L. J. \& Becker, S. (2018). Achievement goals, behavioural engagement, and mathematics achievement: A mediational analysis. Learning and Individual Differences, 68, 12-19. DOI: 10.1016/j.lindif.2018.09.006

Richardson, M., Abraham, C. \& Bond, R. (2012). Psychological correlates of university students' academic performance: A systematic review and meta-analysis. Psychological Bulletin, 138(2), 353387. DOI: $10.1037 / \mathrm{a} 0026838$

Samuels, P. (2016). Advice on Exploratory Factor Analysis. https://www.researchgate.net/publication/319165677_Advice_on_Exploratory_Factor Analysis Utolsó letöltés: 2021. 07. 23. DOI: 10. $13140 /$ RG.2.1.5013.976

Schroeder, C. M. \& Prentice, D. A. (1998). Exposing Pluralistic Ignorance to Reduce Alcohol Use Among College Students1. Journal of Applied Social Psychology, 28(23), 2150-2180. DOI: 10.1111/j.15591816.1998.tb01365.x

Shelton, J. N. \& Richeson, J. A. (2005). Intergroup Contact and Pluralistic Ignorance. Journal of Personality and Social Psychology, 88(1), 91-107. DOI: 10.1037/0022-3514.88.1.91

Shen, B., McCaughtry, N., Martin, J., Garn, A., Kulik, N. \& Fahlman, M. (2015). The relationship between teacher burnout and student motivation. British Journal of Educational Psychology, 85(4), 519-532. DOI: 10.1111/bjep.12089

Shukla, K. D., Kuril, S. \& Chand, V. S. (2020). Does negative teacher behavior influence student self-efficacy and mastery goal orientation? Learning and Motivation, 71. DOI: 10.1016/j.lmot.2020.101653

Siegler Anna (2020). Iskolai bántalmazás a diákok perspektívájából. Iskolakultúra, 30(7), 61-75. DOI: 10.14232/iskkult.2020.7.61

Sinkkonen, H.-M., Puhakka, H. \& Meriläinen, M (2014). Bullying at a university: Students' experiences of bullying. Studies in Higher Education, 39(1), 153-165. DOI: 10.1080/03075079.2011.649726

Smith, E. R., Mackie, D. M., Claypool, H. M., Csertő, I., Danczi, C., Ehman, B. \& Pántya, J. (2016). Szociálpszichológia. ELTE Eötvös Kiadó. 
Svenson, O. (1981). Are we all less risky and more skillful than our fellow drivers? Acta Psychologica, 47(2), 143-148. DOI: 10.1016/0001-6918(81)90005-6

Szabó Éva \& Labancz Ágnes (2015). „Én nem helyeslem, de a többiek biztosan" Normák és vélt-normák múködése és mérése az iskolai osztályokban. In Kovács Judit (szerk.), Szociálpszichológiai tanulmányok a Szociál- és Munkapszichológiai Tanszék fennállásának 25. Évfordulójára. Debreceni Egyetem. 77-97.
Szöllősi Gábor (2019). Az egyetemi hallgatók megtartását segítő eszközök a nemzetközi gyakorlatban: Elméletek és módszerek. Szociális Szemle, 12(1-2), 4-26. DOI: 10.15170/socrev.2019.12.01-02.01

Tatar, M. \& Yahav, V. (1999). Secondary school pupils' perceptions of burnout among teachers. British Journal of Educational Psychology, 69(4), 457-468. DOI: 10.1348/000709999157824

Varga Júlia (2010). Mennyit ér a diploma a kétezres években Magyarországon? Educatio, 3, 370-3832.

\section{Absztrakt}

A tapasztalatok szerint a tanulmányi sikeresség nem csak az egyéni készségektől függ, hanem társas tényezők is befolyásolhatják. A társas normák között elkülöníthetünk leíró, személyes és előíró normákat, vagyis a viselkedések gyakoriságát, a személyes attitüdöt, és a többi csoporttagnak tulajdonított vélekedésre vonatkozó elképzeléseket. A különböző normák együttesen alakítják ki hatásukat az egyén viselkedésére, amelyben megjelenhet a konformitás jelensége is. Tekintettel arra, hogy egyetemisták körében hazai környezetben keveset vizsgált a tanulmányi motiváció és a normák kapcsolata, kutatásunk célja az egyetemi hallgatók leíró, személyes és elöíró normáinak feltárása volt.

A vizsgálatban online kérdőíves módszert alkalmaztunk, 337 egyetemi hallgató önkéntes részvételével. A kérdőívek között a demográfiai adatokat feltáró kérdéseken kívül szerepelt egy 23 tételből álló normavizsgálat, a Célorientációs Kérdőív és az Észlelt Tanári Kiégés Kérdőív.

Az adatok rámutattak arra, hogy a különböző viselkedések előfordulásának észlelt gyakoriságában nagy különbségek vannak. Elsősorban a negatív, csalásra és motiválatlanságra utaló tételek észlelt gyakorisága volt alacsony. Az adatok alátámasztották a többszörös tudatlanság jelenségének előfordulását, vagyis a személyes és az előíró normák közötti jelentős különbséget. A normák a feltáró faktorelemzés szerint három csoportba, a pozitív és negatív viselkedések, illetve a proszociális magatartásformák közé sorolhatók. A személyes attitüd tekintetében nemi különbségeket is találhatóak: a pozitív viselkedések a nők, a negatív magatartások pedig a férfiak körében elfogadottabbak. A közelítő-elsajátító célorientáció összefüggést mutatott a pozitív normákkal, míg az észlelt tanári kiégés a negatív viselkedésekkel állt kapcsolatban.

A vizsgálat megerősítette az előfeltevést, miszerint a pozitív és negatív csoportnormák kapcsolatban állnak a motivációval, illetve az oktatók kiégésének észlelésével. A többszörös tudatlanság jelensége a legtöbb viselkedés esetében megfigyelhető volt, ami magyarázatul szolgálhat arra, hogy bizonyos egyetemi közösségekben hogyan terjednek el a tanulási sikerességet gátló csoportnormák. A vizsgálat eredményei fontosak lehetnek a felsőoktatási lemorzsolódás jelenségének megértésében. 